Ryszard Nycz, Kultura jako czasownik. Sondowanie nowej humanistyki, Wydawnictwo Instytutu Badań Literackich Polskiej Akademii Nauk, seria "Nowa Humanistyka”, t. XXXIX, Warszawa 2017

\title{
Wyjście z laboratorium
}

ABSTRACT. Momro Jakub, Wyjście z laboratorium [Egression from the lab]. „Przestrzenie Teorii” 29. Poznań 2018, Adam Mickiewicz University Press, pp. 365-379. ISSN 1644-6763. DOI 10.14746/ pt.2018.29.17.

The article is a critical insight into Ryszard Nycz's theoretical and antropological project included in his book, Culture as a Verb. Sounding out New Humanities. The fundamental argument is based on the archeology of Nyczean concepts, and their philosophical and socio-political implications. The analytical process focuses on three points. Firstly, the issue is the non-reducing meaning of the cultural experiment, which is the foundation of the "new" epistemology. Secondly, the question is the new idea of temporality, historicity, and relations between nature and culture. Thirdly, the focus is on the concept of praxis.

KEYWORDS: new humanities - cultural praxis - criticalness - nature-culture

Musimy wynaleźć nowe sposoby inwencji.

Pablo Picasso

Istotna jest nie tylko prawda jako taka, lecz także droga do niej prowadzqca

Karol Marks

Od razu należy powiedzieć, że po publikacji Kultury jako czasownika, najnowszej książki Ryszarda Nycza, krajobraz teoretyczny zmienił się za sprawą wyłożonych w niej tez i zanotowanych obserwacji do tego stopnia, że nie sposób już myśleć o tym, co nowe w humanistyce o i pokrewnych jej dziedzinach ludzkiej działalności bez odniesienia do świata oraz sposobów widzenia tego świata, które proponuje autor. Książka Nycza jest w tym sensie bardzo podobna do wszystkich wcześniejszych jego studiów: począwszy od Sylw wspótczesnych i Języka modernizmu, w których szukanie gatunkowej dominanty literackiego radykalnego, bo zasadniczo eksperymentalnego modernizmu, oraz odpowiedzi na niemal pytanie-obsesję o status 
podmiotu poznawczego w odczarowanym świecie, doprowadziły do autora do zagadnienia transgresji estetycznego modernizmu w imię nieokreślonej jeszcze wtedy dobrze (nie tylko w Polsce, ale i na świecie) ponowoczesności; przez Tekstowy świat, sugerujący obowiązywanie specyficznego, bo literaturoznawczego rozumienia filozofii języka Jacques'a Derridy, po koncepcje „tropu rzeczywistości” i wynikających z niej pomysłów na doświadczenie oraz - last but not least - współczesną rzeczywistość zmian kulturowych. Droga myślenia Nycza jest zatem dość wyraźna: od afirmatywnej rozbiórki strukturalizmu, przez nową koncepcję tekstu, a zatem ujęcia lektury jako aktu tyleż epistemologicznego, co etycznego, wedle którego „inny” pojawia się właśnie poprzez literaturę, rozumianą jako szczególny tryb mówienia i znaczenia, do podjęcia intelektualnego ryzyka, jakim jest nie tylko proponowanie „czegoś nowego”, ale również inwencyjna i pojęciowa praca, zmierzająca do tego, aby ową „nowość” nazwać, nie niszcząc jej zupełnie swoim dyskursem. W tym sensie, rzecz jasna, najnowsza książka Nycza jest jego najciekawsza propozycja, w myśl zasady sportowo-muzycznej: „jesteś tak dobry, jak dobra była twoja ostatnia płyta/jaki był twój ostatni mecz".

Mówiąc poważnie, Kultura jako czasownik, zaopatrzona w obrazową kategorię „,sondowania”, zapuszczania się w głąb, swoistego badania, chwilowego i zależnego od najrozmaitszych, względnych okoliczności, to książka zniewalająca nie tylko dlatego, że raz po raz, czytając ją, dotykamy naszej aktualności (słowo, być może, istotniejsze niż namiętnie stosowana przez autora „nowość”). A jak przenikliwie powiada Nycz w kilku fragmentach swoich wywodów, przywołując to Franza Schuberta, to Henryka Markiewicza: nowością nie jest to, co dane w jednym konkretnym momencie czasoprzestrzennym, nie jest nią również proste uobecnienie niewykorzystanych potencjalnych możliwości w tym, co zapomniane, co spoczywa, by użyć pięknego sformułowania Hegla, w „ciemnym szybie niepamięci i historii”, lecz to wynajdywanie melodii do słów pieśni, które znamy niby od zawsze, ale dopiero w aktualności, która wiąże nasze życie i naszą obecność w kulturze w postać tego, co dane, oraz tego, co dynamicznie rozrywa tę egzystencjalną i ontologiczną stabilność. Niczym u Schuberta, Schillera, Baudelaire'a i innych modernistycznych mistrzów, nowość pojawia się jako coś oczywistego, jako melodia czy sposób pisania, jako wyobraźnia, pisanie i porcja wiedzy, o których myślimy, że były z nami od zawsze, ale... trzeba było je dopiero wymyślić, to znaczy w głębokim sensie urzeczywistnić. Nowość jest zatem pewnym sygnałem, a czasami nawet literalnym, cielesnym znamieniem, którego nie wystarczy odczytać - nie da się odszyfrować o tyle, o ile nie jest ona w ogóle językiem. Można by powiedzieć, że sygnały owe są zarazem zapowiedzia jakiejś nowej formy realności, której nie rozumiemy, jak i punktem-znakiem tego, co dzieje się w czasie teraźniejszym, owej tem- 
poralnej przemiany (chyba jednak nie zawsze procesu, jak chciałby Nycz), jaka zachodzi w otaczającym nas środowisku.

Widać więc wyraźnie, że u Nycza zderzają się bodaj dwa najważniejsze problemy współczesności, zakreślające granice nauk o człowieku i nauk społecznych. Po pierwsze chodzi o zdarzeniową koncepcję temporalności, która, rzecz jasna, można wywodzić z czterech, przeciwstawnych w gruncie rzeczy tradycji: postdekonstrukcji (po Derridzie, głównie u Jean-Luca Nancy'ego, Martina Hägglunda, ale także po części Giorgio Agambena); współczesnej filozofii immamencji, wypływającej z nowoczesnej reinterpretacji Spinozy oraz Platońskiego idealizmu (rozwinięcie filozofii Gilles'a Deleuze'a, Alain Badiou i jego uczniowie spod znaku realizmu spekulatywnego, a także „postoperaiści” z Paulo Virno na czele); antropologii, a zwłaszcza najnowszej antropologii nauki i techniki (od Nigela Rapporta po Bruno Latoura); teorii krytycznej i, jak ją określa Nycz, humanistyki zaangażowanej (od Jacques'a Rancière'a, przez Petera Sloterdijka, po „szkołę słoweńska”). W każdym z tych czterech quasi-paradygmatów problem czasowości odsłania się wtedy, gdy ujawnia się niewystarczalność nowoczesnych dyskursów lub kiedy okazuje się, że wyznaczane przez nie ramy pojęciowe stają się zbyt ciasne, kiedy zarówno nowoczesna hegemonia biegu sensownej, a w każdym razie celowej Historii, jak i jej ponowoczesna rozbiórka w wydaniu opiewania „małych narracji” czy tożsamościowej „płynności” nie mówią nic o czasie współczesnej, w którym różnica antropologiczna jest zarazem różnicą w dysponowaniu czasem i zdolnością do regulacji temporalności, kiedy - w konsekwencji czas ludzki nie jest zupełnie inny od czasu natury; kiedy poznanie nie może być jedynie funkcją teoretycznego, hipostatycznego i bezczasowego modelu samowiedzy, lecz istnieje o tyle, o ile neuro- i bionaukowa refleksja nad postrzeganiem, doznawaniem, przetwarzaniem bodźców i danych mogą stać się elementarnym warunkiem uogólnionej nauki o świadomości; kiedy - ostatecznie - nie wystarczy już proklamować, w trybie zaklinania rzeczywistości za pomocą konstruktywistycznej zmiany „słowników” czy „tożsamości”, lecz na nowo przemyśleć społeczny wymiar tworzenia się wiedzy i sposobów jej użytkowania, powstawania instytucji nauki i polityki, która za nimi stoi. Innymi słowy, dla Nycza kultura nie tyle ,jest” już czymś gotowym i w pełni symbolicznie obecnym, co „staje się” formą epistemiczną i egzystencjalna, której zapowiedzi widzimy zarówno w naszych projektodawczych działaniach, jak i nieświadomych odruchach poznawczych, w ciekawości, która „od zawsze" działa niczym proces - jest już w nas i nas zmienia. Toteż zamiast charakterystycznych dla późnonowoczesnego poznania historycznego kategorii nieciagłości, cięcia epistemologicznego i przemocy archiwalnej Nycz wybiera refleksję nad indeterminizmem czasu kształtującego pojawiające się obiekty wiedzy oraz temporalną przygodność podmiotów. 
Kiedy Nycz używa swojej ulubionej formuły poznania jako działania „retroaktywnego”, to znaczy ze skutkiem wstecznym, nadającym impet antykwarycznym reliktom przeszłości, to ocala nie tylko myślenie historyczne, ale również legitymizuje refleksję o przyszłości, a nawet marzenie, które jak się zdaje, stoi za formuła „,nowej humanistyki”. Uważny czytelnik rozpozna ten trop w zamykającym, przepięknym eseju o Brunonie Schulzu, w którym autor, posługując się figurą ze słynnej książki Derridy o Marksie, używając pojęcia „mesjańskości”, mówi w istocie o przyszłości człowieka jako procesie nieskończonej symbolizacji - teoretyczny podmiot nowoczesny, którego fantazmatem była separacja od zewnętrznego świata i pielęgnacja tej granicy, odsłania nagle własną kruchą skończoność; zagubiony w labiryncie wytwarzanym przez nieokiełznane procesy symbolizacji, dostrzega szansę na inną formę życia dzięki pewnej zdarzeniowej energii kultury niezapowiedzianej przyszłości, za pomocą której wszelako da się, być może, odzyskać utracone światy przeszłości. To właśnie literatura, czy szerzej: sztuka i doświadczenie estetyczne stanowią szczególne medium i miejsce, w których poznanie spotyka się z refleksją na temat stanu wiedzy (tego, co możemy poznać) i tego, jak możemy tyleż doświadczyć, co wymyślić wolność (to, co możemy czynić).

Ten praktyczny lub, jak często pisze Nycz, „czynnościowy” charakter humanistycznego poznania wywodzi się z krytyki nowoczesności, a - mówiąc ściśle - z refutacji pewnego modelu naukowej modernizacji. Nie wydaje się bowiem, że Nycz chce całkowicie odrzucić nowoczesność w jej rozmaitych wariantach i wcieleniach, ale też nie bardzo pragnie ją ocalić. Innymi słowy, nowoczesność dla autora Kultury jako czasownika przestaje być problemem poznawczym, estetycznym i etycznym, proklamowana przez niego „nowość”, dzięki której możemy odzyskać przeszłość dla teraźniejszości i w imię przyszłości, to zasadnicze odejście od syntetycznej dialektyki czasu na rzecz przyjęcia heterogenicznego czy sieciowego, służy zbudowaniu holistycznej wiedzy jako doświadczenia. Odrzucenie nowoczesności dokonuje się tutaj w podwójnym i podwójnie artykułowanym trybie: jako - po pierwsze - nazwy dla różnych sposobów społecznej modernizacji (emancypacja rozumiana w ramach tradycyjnej teorii krytycznej) oraz estetycznej autonomii (tak zwany wysoki modernizm) oraz wzajemnej korelacji polityczności i estetyki (awangarda), a po drugie - jako zdolności do separacji świata nauki, a więc pewnych apriorycznie zagwarantowanych procedur eksperymentatorskich, od świata doświadczenia, rozumianego jako - mniej lub bardziej tymczasowa - konfiguracja doznań, afektów, emocji i światopoglądów składających się na to, co filozofia zwykła nazywać Lebensweltem. Diagnoza o zastapieniu czasu przeżywanego czasem nauki nie jest wszelako nowa, sięga bowiem fenomenologii Husserla, a dalej Heideggera i konsekwencji, jakie wynikają 
z jego - co najmniej - dwuznacznej postawy wobec zagadnienia techniki, i dość jednoznacznego stosunku do procesów modernizacyjnych, których był jednoznacznym i bezwzględnym krytykiem. Z pewnościa jednak nowe sa, mówiąc najprościej, pojęciowe opracowania dokonane przez Nycza i teoretyczny argument, jaki przedstawia w swej książce.

Wydaje mi się, że w namyśle autora kluczowe są trzy punkty odniesienia: jeden - podany wprost, dwa pozostałe - skrzętnie ukryte, ale o takiej samej mocy oddziaływania co pierwszy. W pierwszym przypadku chodzi o koncepcje Bruno Latoura, wywiedzione tyleż z jego tekstów o historycznej antropologii nauki (książki o Pasteurze, tomu rozmów ze swym nauczycielem, Michelem Serres'em, studia przypadków: historia fantazmatu próżni, geometrii itd.), co generalnych intuicji i tez zaproponowanych w książce Nigdy nie byliśmy nowocześni. Nycz, choć pozostaje dużo ostrożniejszy i nie powtarza po prostu tez Latoura, ożywia to rozpoznanie niejako z innej strony, to znaczy w innym miejscu niż Latour sytuuje najważniejszy problem współczesnej episteme. Punktem wspólnym pozostaje wszelako nauka i/ lub wiedza „poza zasadą nowoczesności”. Przypomnijmy dla porządku, że Latour wymienia trzy główne języki stanowiące fundament nowoczesności (zwłaszcza w jej dojrzałym, czy późnym wydaniu): naturalizację (symbolizowaną nazwiskiem E.O. Wilsona), socjologizację (P. Bourdieu) oraz dekonstrukcję (J. Derrida). Podział ten, choć zgrabny, powtarza w gruncie rzeczy wcześniejszy o kilkadziesiąt lat pomysł zawarty w słynnym tekście Jürgena Habermasa z czasów gorącego sporu o granice nowoczesności i status postmodernizmu, Moderna: niedokończony projekt. Niemiecki filozof, za Kantem, ale przede wszystkim za Maxem Weberem z jednej strony i koncepcjami współczesnego czy nowoczesnego doświadczenia estetycznego, z drugiej, pokazuje, w jaki sposób architektoniczna koncepcja myślenia zawarta w trzech Krytykach prowadzi do obecnego stanu podziału i niemożliwej do zniwelowania separacji między poszczególnymi dyspozycjami podmiotowymi (obejmującymi tak jednostki, jak i wspólnoty). Stąd autonomizacja sfery estetycznej i jej wolnego (w tym także sensie: niezobowiązującego społecznie) sądu, stąd status normatywnego porządku moralnego, stąd wreszcie uzasadnienie działania i pozycja rozumu technicznego, który ostatecznie staje się dominanta , „czasu odczarowanego”. Dla Latoura podobnie: nowoczesne projekty (ale też i hipostazowane monstrum-alegoria jednej, homogenicznej Nowoczesności) parcelują nasze doświadczenie w imię fikcji teoretycznych, fikcji, które - niczym ideologiczna camera obscura - zaciemniają przygodny i procesualny charakter naszego życia i jego sposobów poznania. Jak z wrodzoną sobie ozdrowieńczą dezynwolturą często i w różnych miejscach swego dzieła powiada: „Nie jest naszą wina, że jesteśmy równocześnie zwierzętami społecznymi, biologicznymi i językowymi”. Można zatem powiedzieć, że 
o ile francuski filozof traktuje fragmentację ludzkiego doświadczenia jako segmentację pojmowania rzeczywistości za pomocą analizy i syntezy, o tyle dla Nycza szukanie nowej formy holistycznej staje się de iure i de facto tworzeniem nowej eksperymentalnej wiedzy o człowieku. Odejście od dualizmu puryfikacji (czystej, bezprzymiotnikowej, jak powiada Nycz, teorii) i hybrydyzacji (definiowanej wyłącznie jako wynik negacji krystalicznej ontologii) to, jak się zdaje, punkt wyjścia do odrzucenia ducha nowoczesnego w imię „nowego” poznania jako ucieleśnionego pragnienia wiedzy.

To przejście doskonale widać wtedy, gdy spojrzymy na rozdziały książki Latoura, poświęcone „kryzysowi krytyki” oraz - równolegle - na fragmenty z książki Nycza o koncepcji tekstu i lektury jako modelu ,jednostkowo-mnogiego" (formuła Jean-Luca Nancy'ego) bycia-w-świecie (z jednej strony) oraz wydawałoby się przebrzmiałego problemu „inności”. Choć, jako się rzekło, filozofia Latoura jest dla Nycza ważna, to jego odejście od nauki w stronę wiedzy wydaje się aż nadto symptomatyczne. Rozważanie statusu naukowości wiedzy i nie-wiedzy tworzy quasi-system myśli, w którym koncepcja i wypracowana zawczasu teoria gwarantuje - w mniejszym lub większym stopniu - poszukiwanie reguł, zasad, ale w związku z tym, nieregularności, marginesów i odstępstw. Tytuł książki Latoura to tylko i aż odwrócenie modernistycznego paradygmatu powstawania wiedzy, to - innymi słowy negacja tego, co przeszłe, dzięki której naukowa antropologia wyrzeka się swej krytycznej mocy.

Formuła „kultura jako czasownik” pozwala odejść od tych dylematów prawdziwościowego, teoretycznego czy pragmatycznego uprawomocnienia nauki i przejść do rzeczywistości, w której zmiana w obrębie kultury (jako zmiana tyleż symboliczna, co historyczna, tyleż afektywna, co pojęciowa) staje się - za każdym razem - inną formą interwencji w zastaną czasoprzestrzeń, interwencji, a więc takiej zmiany (czy może nawet: metamorfozy) podmiotu i poznawanego czy tworzonego przezeń obiektu, którego istnienie uzasadnia się tylko w tym procesie. Nycz niezwykle często mówi w tym wypadku o wzajemności oddziaływania subiektywności i świata. Wydaje się, że tę relacyjność można przeciwstawić dwóm bardzo mocno dziś obecnym sposobom refleksji: z jednej strony - myśleniu sieciowemu, w którym podstawę stanowią nienormatywne, statystyczne czy nienormatywne sposoby rachunku, z drugiej - wszelkie, zazwyczaj bardzo radykalne, modele ontologii, wraz z nowym spinozyzmem, czy realizmem spekulatywnym, w których byt albo jest wynikiem niepowstrzymanej życiodajnej siły, która go uobecnia (conatus), albo jest nim wszystko, co istnieje, niezależnie od jakości materii i poziomu stanów mentalnych oraz biochemicznej i fizjologicznej organizacji kognitywnej (drzewo, samochód, telefon, małpa, człowiek, księżyc). I w jednym, i w drugim przypadku odwrót od myślenia poprzez język lub 
w wytworzonych przez niego kategoriach jest aż nadto widoczny. Latour czy Castells będa poszukiwali prawidłowości i dysfunkcji w stałych organizujących praktyki i fantazmaty społeczne, z kolei Virno czy Meillassoux będą szukać przygodności (a więc pewnej serialnej, niczym w muzyce, struktury rzeczywistości) jako pewnej formy niezbywalnej konieczności - świat istnieje nie tylko niezależnie od człowieka, od jego świadomości, ale - co więcej - jest to obecność, której nie da się do owej antropologicznej formy zredukować.

Między determinizmem i koniecznością pojawia się jednak luka, której żadna forma ontologii ani żadne pojęcie nie jest w stanie zapełnić. To właśnie tu pojawia się język, a mówiąc ściślej: forma symboliczna lub, co jest mi bliższe, pewna relacyjna zmienna, czyli mediacja. Dla Nycza wciąż, jako się rzekło, jej najpojemniejszą formułą pozostaje tekst czy też raczej: „literatura: litery lektura”, jak mówił niegdyś przy okazji analizy Wagonu Adama Ważyka, a więc czytanie okazuje się nadal podstawową regułą egzystencjalną (także w sensie „ćwiczenia” z udziału w świecie). Nie można się jednak dać zwieść: nie ma już granic tekstu, bo i sam tekst jako poręczna metafora stanu rzeczywistości, w których żyjemy przestał już cokolwiek mówić. Pod tym względem widoczne jest w książce Nycza dość dramatyczne napięcie, między ograniczeniem kreatywnej funkcji tekstu i „czytania świata” (formuła Umberta Eco), a wyjściem z tekstualnego archiwum w stronę innej pojęciowości i szerszego rozumienia tego, co nas, nasze „współdzielone” formy życia - poprzez nowe i stare pojęcia - w tym świecie zapośrednicza. Toteż projekt Nycza (książka, jak zwykle u tego autora, to work in progres) określiłbym mianem „kulturowych dialektyk współczesności”. W odróżnieniu od nowoczesnych ujęć dialektyki nie chodzi o jej jeden, wyszlifowany filozoficznie, model (pozytywno-rewolucyjny, od Marksa do Lukácsa, czy negatywno-estetyczny, od Marksa do Adorna), lecz o „nowe” dialektyki, które ujawniają się w wielości „światów-wiedzy”, do których odsyłają i w których pozwalają się zakotwiczyć. Tytułowy „czasownik” to nie tylko proces i zmienność w obrębie kultury, to także - jak sądzę - przede wszystkim ich krytyczny, ale nie redukcyjny wymiar. W ten sposób także uzasadnia się rozumienie języka jako użycia, nie tyle może jako gier językowych, dzięki którym ich uczestnicy moga, choć nie muszą się spotkać $\mathrm{w}$ akcie porozumienia, ile jako medium relacyjne i podlegające niedającemu się zaplanować procesowi kształtowania. Propozycja Nycza nie jest więc ani lingwistyczno-strukturalna (która przeżywa obecnie swój skądinąd zasłużony renesans), ani obrazowa - język jako medium relacji sytuuje się poza zasada reprezentacji i w tym sensie poza metafizyką uobecnienia i wtórnej repliki. To podejście widać zwłaszcza w drugiej części książki, kiedy autor testuje rozmaite warianty tego nieudualistycznego myślenia - pisarstwo krytyczne Jana Błońskiego jako teatralny performatyw, krytyczna praktyka fragmentu Theodora W. Adorna 
jako przykład poznania poprzez konstrukcję tekstu, czyli wizję estetyczną (w której pobrzmiewa wyraźnie wątek życia estetycznego Kierkegaarda), czy dialektyka osobliwości i systemu w projekcie teoretycznym Janusza Sławińskiego. Jako konsekwencja tego stanowiska pojawia się jednak, zbyt pospieszna, jak sądzę, konkluzja, że właściwie tak rozumiany język może być metaforą (czy ostrożniej: metakategoria) doświadczania świata. Jeśli tak, to w strukturze metafory ginie idiosynkratyczność każdego użycia języka, każdego aktu mowy, a także - co nie mniej istotne - zaciera się swoistość innych, „mocnych” praktyk symbolicznych, czyli społecznych, politycznych oraz naukowych użytków z języka. Jeśli przypomnimy sobie tytuł książki Jana Błońskiego, jednej z najważniejszej postaci dla Nycza, który brzmi Miłosz jak świat, to widać wyraźnie, że metaforyczne uogólnienie, czy nawet hiperbola stanowi kontrargument wobec kruchego (w rozumieniu Judith Butler) życia, usiłującego odnaleźć uzasadnienie dla własnej przygodności w gąszczu praktyk mowy. Obcując z dziełem, które, ,jest” jak świat, musimy z konieczności zapomnieć o wymiarze egzystencjalnej nieciagłości i niepewności, która uściśla się w owym retroaktywnym geście translacji przeszłości z perspektywy teraźniejszości i owego „teraz” konkretnej formy życia, która w tym wypadku - zostaje przysłonięta uniwersalną płaszczyzną tekstu. Być może jednak to wahanie od tekstu-świata do świata-bez-metafory, świata mnogości form życia daje się najpełniej objaśnić w taki właśnie sposób.

Poszukiwania Nycza oscylują nieustannie wokół podstawowego problemu poznawczego: czy możliwa jest wiedza „przedkulturowa”? Czy istnieje „fakt” czy istnieja „dane”, które oddziałują ze swej numerycznej istoty? Czy niezapośredniczone doświadczenie ma jakikolwiek sens? Z jednej strony: matematyczny model nauki i/lub filozofii, z jej - zazwyczaj słusznym roszczeniem do apriorycznej prawdziwości, z drugiej - prymat jednostkowej lub zbiorowej samowiedzy, służącej albo swej autonomii (posiadania czy odkrywania wiedzy jako ideału podmiotowości), albo kłopotliwej heteronomii. Właśnie po stronie tej drugiej sytuuje się Nycz. I w pewien sposób wykonuje gest, na który, jak się zdaje, powinniśmy się zdobyć - gest wolności wiedzy. Ten fantastyczny moment, w którym cała skumulowana wiedza łączy się i rozpada w jednej chwili, kiedy ślady przeszłości plastycznie tworzą teraźniejszość, jak i są przez nie tworzone, i kiedy - na koniec - uwolnienie od tej wiedzy jest zarazem zapowiedzią przyszłości, to absolutna nowość i u samego Nycza, i w humanistyce. Hegel niegdyśs opisywał to doświadczenie jako „puszczenie wolno”, czyli doprowadzenie bezwzględnej dialektyki rozumu, pojęcia i tego, co inne (w tym i języka) do chwili, kiedy świat staje się zrealizowaną mnogością. Tym chyba jest właśnie ów czasownikowy model kultury, w której nie trzeba rezygnować z zasady krytycznej, aby stworzyć „nowe” pole wiedzy. Jeśli, w myśl tradycji Nietzschego i Benja- 
mina, krytyka jest destrukcja, to znaczy swego rodzaju próbą ogniową dla stosowanych przez nas kategorii i teoretycznych pomysłów, to dla Nycza niejako w normatywnym ruchu musi stać się dialektyczną mediacja: pośrednictwem między formami czasu i konkretnymi przypadkami, które wytrącają nas z poznawczej rutyny. Ale takie podejście do krytyki pokazuje coś jeszcze, a co jest „duchem”, czy „widmem” całej książki, czyli początek, a raczej jego niemożliwość.

W Kulturze jako czasowniku problem początku zostaje zniesiony: nie ma sensu pytać o arche nowoczesności, o prymat danego języka czy danej wyobraźni, bowiem to, co istotne, to, co możemy wysupłać z dialektycznych węzłów czasu, nigdy nie objawi się w czystej, rzekłbym, hegemonicznej postaci. Jeśli Hegel mówił o mechanizmie „puszczenia wolno” jako zasadzie wolności nowoczesnej egzystencji, ma ona znaczenie jedynie wtedy, gdy przyjmiemy pewne fundamentalne założenia: po pierwsze: nie istnieje wiedza bezzałożeniowa, po drugie - nie ma „wiedzy pierwszej”. Innymi słowy, wolność i teoretyczna konieczność służą czemuś innemu. Dwieście lat temu Hegel próbował ująć wiedzę w idealistyczny System, w którym pojęcie stałoby się substancja, czyli - ostatecznie - życiem. Dziś powroty do systemu muszą z konieczności prowadzić albo przez złożone (głównie topologicznie, vide „późny” Lacan) modele matematyczne lub, mówiąc najogólniej, przyrodnicze (teoria systemów, nanogenetyka, teoria plazmy, teoria strun, plastyczność jako pojęcie i jako zmiana w mózgu, jak u Catherine Malabou...), albo kończą się wątpliwej jakości „słabą” teorią (najczęściej w wydaniu hermeneutycznym). Czy zatem życie wiedzy, życie w wiedzy, jakie przedstawia nam Nycz, daje szansę na uzgodnienie przypadku (zarówno w znaczeniu pewnego wycinka $\mathrm{z}$ danej formacji historyczno-kulturowej, jak i jako przygodności matematyczno-egzystencjalnej) i konieczności: zdarzenia i struktury, afektu i pojęcia? Wydaje się, że obraz rysowany przez autora, oprócz drogi zapośredniczenia, wskazuje na obowiazywanie starej Kantowskiej prawdy, głoszącej, że „pojęcia bez danych naocznych są puste, a doświadczenia bez pojęć - ślepe".

W tym kontekście wyłania się szereg pytań o to, o jakim doświadczeniu mówi Nycz. Innymi słowy: o jaki rodzaj praktyk epistemicznych chodzi? Od autora otrzymujemy, co znamienne, rodzaj taksonomii humanistycznych działań. Nycz z precyzją chirurga kroi tkankę współczesności, która swoje miejsce odnajduje między pisaniem afektywnym a zaangażowaniem, w mniej lub bardziej tradycyjnym stylu. To uporządkowanie, niczym na tablicy Linneusza, nie tworzy systemu, lecz odsłania rodzaj morfologii „nowej” kultury. Ale taki podział jest, jak wiadomo, arbitralny i autor świadomie płaci cenę za tę arbitralność kryteriów. Wydaje się, że próba takiej morfologicznej obiektywizacji zjawisk kulturowych, które raz po raz się „sonduje”, 
nasuwa pytanie o to, czy wszystkie z już opisanych oraz tych, które opisane dopiero zostana, są sobie równe. Czy humanistyka wciagnięta w ozdrowieńczy kontakt ze sztuką mówi nam więcej o nas samych i ciekawiej profiluje nasze sposoby postrzegania i poznania, niz humanistyka realizująca się w bezpośredniej ingerencji w tkankę społeczna, której zwolennicy traktuja wypracowane narzędzia teoretyczna do pracy na rzecz zmiany społecznej? $\mathrm{Z}$ pewnością nie ma tu dobrej odpowiedzi, co wynika nie tylko przyjętej przez Nycza metodologicznej strategii, lecz również z ujęcia „nowości” jako splotów tego, co w teraźniejszości się namnaża. Niczym w biologicznym, biochemicznym procesie spontanicznego i nieprzewidywalnego zawęźlania się podstawowych struktur białkowych, z których tworzą się przygodne i niedające się przewidzieć układy życia, tak epistemologia kultury niejako z konieczności staje się heterogeniczną i metamorficzną całością-spękana, znikliwą oraz tymczasową i zdarzeniowa, teoretyczną i ucieleśnioną w ludzkiej lub nie-ludzkiej - osobliwości.

Problem dotyczy również czegoś innego. Epistemologiczne zerwanie z nowoczesnością w jej projektodawczym wymiarze na rzecz, by posłużyć się raz jeszcze terminologia Latoura, nowej Konstytucji, usuwa pytania o status refleksji nad tą częścią kultury nowoczesnej, która nie opiera się ani na strukturalnej homologii pojęć, ani na przyległości (jak w modelu nauki Latoura), ani oddzielenia (jak u realistów spekulatywnych czy w matematyczno-platońskiej filozofii Badiou), lecz na antynomii. Implikacje tej negacji sa, jak się zdaje, całkiem intrygujące. Jeśli bowiem przyjąć, że zasada sprzeczności (aż do myślenia w kategoriach aporii) stanowi nie tylko warunek logiczny, lecz również antropologiczny nowoczesności, w różnych jej odsłonach, a więc kiedy antytetyczność nie daje się przezwyciężyć, to przyjąć należy również, że nie istnieje praxis poza tą sprzecznością. Ten quasi-aksjomat prowadzi $\mathrm{w}$ trzech kierunkach. Po pierwsze w stronę epistemologii symptomu, czyli psychoanalizy jako rozległego pola „innej” wiedzy, a także kontrfaktycznej nauki. W tym kontekście dość przypomnieć rozważania Freuda z Kultury jako źródta cierpień, gdzie stanowi ona rozsadnik nieredukowalnej podwójności - zarazem chroni nas przed mrocznymi siłami natury, lecz za cenę kastracji symbolicznej, czy dynamikę popędów w Poza zasada przyjemności, czy wreszcie: Lacanowską interpretację postaci Antygony, w którym pięknu śmierci nieodłacznie towarzyszy wybrakowane ziemskie życie.

Drugim punktem odniesienia, mniej - jako się rzekło - oczywistym, jest rozum instrumentalny. Rzecz jasna, pojęcie to ma antecedencje w teorii krytycznej, ale jako jej (nie tyko socjologiczny i teoretyczny) wynalazek w dużej części opisuje naszą współczesności. Kiedy zostawimy na boku komplikacje „dialektyki oświecenia” Horkheimera i Adorna i spróbujemy pod katem panowania racjonalności kalkulacyjnej zobaczyć, jak wielka część nowoczesności, 
ale także i „nowości” jest uzależniona od świata uprzedmiotowienia i fetyszyzmu towarowego, zrozumiemy także dzisiejszy powrót tyleż do „teorii krytycznej” w różnych jej odmianach, co do samego jej źródła, czyli Marksa. Nie jest to, rzecz jasna, Marks dogmatyczny, lecz krytyczny, dla którego naczelnymi kwestiami sa alienacja oraz - kapitalizowana, ideologizowana i estetyzowana - forma życia jako praxis. Rozum instrumentalny to odbicie w krzywym zwierciadle prawdziwego działania, dzięki któremu praca nie jest bezsensowną produkcja, lecz miejscem styku jednostki ze światem i doświadczenia oporu, jaki ten świat wzbudza. Praktyka urzeczywistnia pragnienia oraz marzenia podmiotów i wspólnot na egzystencję wolną od przemocy uprzedmiotowienia, a więc podległości rozumowi instrumentalnemu. Wyobcowanie ze świata praxis staje się wyłącznie procesem urzeczowienia człowieka, dla którego praca jest ostatecznym stadium alienacji.

O ile spora część „teorii krytycznej” (w tym autorzy Dialektyki oświecenia) odrzuca następny krok w myśleniu o człowieku w kategoriach formy równocześnie materialnej i świadomej, czyli rewolucję, o tyle wiele - niezwykle istotnych dla dzisiejszych pomysłów na humanistykę zaangażowaną i krytyczna - propozycji opiera się na przejściu od rozpoznania i uznania człowieka poprzez jego działanie do zmiany czy raczej zerwania rewolucyjnego. Patronami są tu Walter Benjamin i Györgi Lukács, ten pierwszy z powodu quasi-mesjańskiego myślenia o historii, drugi - ze względu na filozofię, której przekroczenie dualistycznego podziału na rozum teoretyczny i rozum praktyczny przynosi efekt w postaci prawdziwie nowoczesnego myślenia jako praktyki. Ale ostatecznie istotne jest coś innego, co zbliża nas do kwestii podnoszonych przez Nycza. Obaj autorzy wskazuja, choć oczywiście z zupełnie różnych perspektyw, na kluczowe miejsce, jakie w myśleniu zajmuje problem reifikacji i fetyszyzacji, które choć z pozoru wyglądają na przebrzmiałe teoretyczne dogmaty, doskonale opisuja stan dzisiejszej dynamicznie zmieniającej się kultury.

Dla Lukácsa w jego bodaj najbardziej doniosłym dziele, wpływem daleko wykraczającym poza marksizm, czyli Historii i świadomości klasowej, największym zagrożeniem jest historyczna pustka, która wypełnia władza determinująca urzeczowienie grup już wykluczonych i podległych prawu czystej przemocy. Samopoznanie nie jest odseparowane od uznania społecznego i zajęcia pozycji politycznej, zaś momenty kryzysowego przesilenia stanowią szansę na rewolucyjne zerwanie z realnym i symbolicznym status quo. Epistemologia idzie tu zatem ręka w rękę z gestem czy ruchem emancypacji, tworząc dialektykę upodmiotowienia poprzez praktykę nabywania świadomości oraz uznania tej pozycji w polu społecznych antagonizmów. Elementem łączącym te dwa wymiary, teoretyczno-indywidualny oraz emancypacyjno-polityczny, jest praca. To dzięki niej praxis, w tym także praktyki 
kulturowe, uzyskują prawomocność, ponieważ pozwalają wyjść człowiekowi ze stanu urzeczowienia. Oczywiście, Lukácsowi chodziło o konkretny moment historyczny międzywojnia, ale sama zasada działa i dzisiaj, zmieniły się tylko warunki. Dość spojrzeć na to, jak konkretne kultury wytwarzają wzorce hegemonii i dominacji, i jak symulują przez to możliwe ścieżki emancypacyjne, wpisując się, jak lata temu przenikliwie dowodził Fredric Jameson, w kulturową logikę totalizującej wartości wymienne, zakazującej wyzwolicielskiego użycia obiektów materialnych. Innymi słowy, nawet (a może przede wszystkim) te właśnie praktyki kultury, które opierają się na płynności, zmienności i sprawczości jako sferze innorodnej wobec anonimowych mechanizmów cyrkulującego kapitału (realnego i symbolicznego), stać się moga przestrzeniami ujarzmienia (najpełniej to widać w znakomitym rozdziale książki Nycza, poświęconym relacjom z Innymi w postkolonialnym czy postzależniościowym wydaniu). Utowarowienie człowieka odbywa się za sprawą ideologii zawartej w systemie fałszywych reprezentacji, wzorców tożsamościowych, które - odwrotnie niż w świecie dojrzewających procesów modernizacyjnych - wymuszają obsceniczną z nimi identyfikację, a nie otwieraja drogi upodmiotowienia. W tym sensie „nowość” staje znakiem „ucieczki do przodu" przed newralgicznym momentem w historii i w efekcie przybiera formę konserwatywnego fetysza proklam, a nie nie realnej, bezustannej zmiany. Fetyszyzm sprowadza kulturę do sieci mechanicznych i kapitałowych zależności, które stają się, o ile można tak powiedzieć, łatwym łupem rozumu instrumentalnego, wytwarzającego fantazmat kultury pozbawionej mechanizmów oporu, a więc przeznaczonej do konsumpcji.

W tym miejscu pojawia się trzeci punkt namysłu Nycza. Reifikacja człowieka oraz wiedza jako towar i fetysz to oczywiście ogromny problem naszej aktualności, który można zawrzeć w pytaniu: czy obecne systemy kulturowe, te, które tworzymy i które rodzą się na naszych oczach, ale pozostają od nas niezależne, sugerują istnienie jakiegoś „zewnętrza”? Czy rzeczywistość XXI wieku, w której nie istnieje żaden obiekt kultury, niebędący zarazem obiektem kapitalistycznego barbarzyństwa, i w której każda forma buntu, każda forma subwersji zostaje wchłonięta i przetrawiona przez Lewiatana rozumu instrumentalnego, daje szanse na „przechwycenie” symbolicznej mocy fetyszu? Odwrotnością tego procesu wydaje się przejście od nowoczesnej koncepcji przyrodohistorii do „nowego” wieloaspektowego rozumienia świata w kategoriach naturokultury. Zmiana jest wyraźna i zasadniczo zmienia układ odniesienia. O ile dla Benjamina czy Adorna nielinearna i niekongruentna historia była miejscem stawania się kultury, o tyle w drugim przypadku powrót autorów najrozmaitszych teorii do Arystotelesowskiej ontologii natury jest aż nadto widoczny. Jeśli wedle jego klasycznej definicji natura istnieje o tyle, o ile ma swoją ontologię, to dzisiejszy spór o relację między 
natura a kulturą dotyczy zakresu obecności i działania technicznej czy technologicznej protezy. Technika, rzecz jasna, nie stanowi już „uzupełnienia tego, czego natura nie jest sama w sobie urzeczywistnić", jak w metafizyce Arystotelesa, ani nie jest techniką w sensie metafizycznego podporządkowania istnienia systemowi reprezentacji, jak u Heideggera, ale okazuje się sposobem porządkowania konkretnego życia uchwyconego in actu. Technika, całkiem odwrotnie niż wskazywałoby jej zdroworozsądkowe rozumienie, nie stanowi zestawu narzędzi i sztucznych operacyjnych maszyn, zewnętrznych wobec człowieka, lecz jest naturalnym sposobem tworzenia siebie przez wchodzenie w nawarstwiajacej się relacje ze środowiskiem.

Wydaje się, że impuls do przemyślenia tej sytuacji płynie z różnorodnych użytków, jakie studia kulturowe czynią z dzieła Waltera Benjamina. I choć, jako się rzekło, teologiczny wymiar tej myśli jest niezbywalny, to strona historycystyczna, a przede wszystkim materialistyczna, wydaje się dziś o wiele istotniejsza. Autor Pasaży jako pierwszy, obok może Sigfrida Kracauera, zauważył siłę rażenia kultury popularnej, W odróżnieniu od potępiającego ją tonu łączącego konserwatystów i progresistów (np. Ortegę y Gasseta z Adornem), Benjamin daje świadectwo swej fascynacji, ale i stara się cały czas opisać cień, jaki rzuca ona na kulturę. Popkultura to świadectwo powszechności, demokracji i codziennej partycypacji w tym, co staje się miejscem wspólnym doświadczenia estetycznego, miejsca i nie-miejsca w mieście, krajobrazu, architektury i muzyki pop, co - innymi słowy - stanowi istotę życia i rozrywki, co w niej samej każe widzieć coś więcej niż tylko ona sama. Ten dynamiczny walor kultury pokazuje dwie rzeczy. Po pierwsze, popkultura ucieleśnia, może bardziej niż inne pole praxis symbolicznej, sprzeczności, impasy kultury i świata symbolicznej oraz kapitałowej wymiany. Po drugie, ambiwalencja ta niemal wrzuca nas w świat dzisiejszy, który jedynie wzmacnia podwójną rolę popkultury. Z jednej strony, jest ona fetyszem wcielonym, zmultiplikowanym pozorem prawdziwego doświadczenia, a więc wartością ekspozycyjną, która spełnia $\mathrm{z}$ kolei funkcję dialektycznego suplementu, staje się formą kapitalizmu jako religii, alienującym i rozbijającym niemal wszelka formę podmiotowości. Z drugiej strony, popkultura nie daje się zrównać do masowej rozrywki, produktu gotowego lub przygotowanego na konkretne zapotrzebowanie, lecz będąc (chcemy tego, czy nie) milieu naszych działań umożliwia, choćby minimalne, gesty krytyczne: nadidentyfikację, przechwycenie, persyflaż, odgrywanie, nienormatywne estetyki i sposoby pisania. Wydaje się, że od tej dwuznaczności nie ma, przynajmniej dziś, ucieczki, ale także staje się ona szansą na wyjście z ideologicznych pułapek, dualistycznych i hierarchicznych namiętności rodzących zrost rozumu teoretycznego i instrumentalnego. 
Wydaje się, że brak tego wątku w książce Nycza jest i znaczący, ale i w sposób fundamentalny zrozumiały. Widać to może bardziej w podtytule niż w „czasownikowym”, głównym określeniu projektu. „Sondowanie” oprócz znaczenia mechaniczno-przyrodniczego odnosi się wszakże do naszych bolesnych doświadczeń: sonda zostaje zapuszczona nie tylko w ostatecznie obojętne dla nas terytorium (ziemi czy wody), ale w nas samych, w głąb naszych ciał, pod ich powłoki i pod skórę; to intruzywne wtargnięcie, w którym badanie i wiedza o działaniu naszego organizmu łączy się z bolesnymi doznaniami fizycznymi. I jeśli nawet potraktujemy tę formułę metaforycznie, to nie zmienia się zasada, której autor z taką przenikliwością broni, czyli reguła upodmiotowienia poprzez cielesną wiedzę. Ostatecznie nie jest ona ani czystą kontemplacją czy poznawczą konstrukcja, ani nie jest dostępna przez systemowe znaczenia i dostępne narzędzia komunikacyjne, wreszcie: nie stanowi osi zaangażowania ani procesu konstruowania podmiotowości. Wiedza ta to phronesis teraźniejszości, której nie da się zredukować do żadnej z form episteme. Podmiot zaś to, jak w różnych swych książkach określa Nycz, bricoleur, majsterkowicz, który, należałoby dopowiedzieć, ma swojego antropologicznego odpowiednika w tricksterze, nadświadomym oszuście, którego działanie nie pozwala nam rozstrzygnać, czy nasze działania w sferze kultury sa jakąś forma „nowej” racjonalności, czy tylko resztką po „starym” humanistycznym czarnoksięstwie.

W projekcie czasownikowej kultury widziałbym dwie niezwykle rzadkie, a przez to tym cenniejsze figury „innej” racjonalności. Pierwsza pojawia się w znakomitym szkicu o twórczości Janusza Sławińskiego. Z pieczołowitej analizy Nycza wyłania się, poza przekonującym portretem uczonego, fascynujący obraz poznawczego antynarcyzmu. Widać wyraźnie, że strukturalistyczne marzenie o obiektywności wiedzy nie było skierowane wyłącznie w stronę naukowej pewności, lecz ujawniało pewną dyspozycję refleksyjnej podmiotowości, która nie byłaby ani podporządkowana jakiejś wyższej instancji (ogólniej Idei, określonej koncepcji Prawdy czy Struktury), ani też nie byłaby całkowicie autonomiczną subiektywnościa, która w świadomościowym geście ustanowienia celebruje własną samodzielność. Bezosobowość wiedzy oraz dyskursu i towarzyszacy im antynarcystyczny odruch nie oznacza wcale śmierci podmiotu ani człowieka, wręcz przeciwnie: dopiero wtedy, gdy przestaje nas więzić obraz świadomości jako jedynego punktu odniesienia, realne staje się ćwiczenie w kulturze, które przynieść może wolność.

Ten splot emancypacji, poznania i egzystencji przenika niemal cała książkę Ryszarda Nycza. Próbuje on ten splot rozwikłać, niemal w imię wyłożonej przez Benjamina metafory pisania i myślenia, rozwijającego się papierowego ptaka, figury, w której ściśnięte płaszczyzny ją tworzące nagle odsłaniają się w całej swej pełni, o której nie mieliśmy wcześniej pojęcia. 
Książka Nycza stawia nas, czytelników, ostatecznie, na progu laboratorium - w niemal normatywnym impulsie autor proponuje nam wyjść z przestrzeni bezpiecznego eksperymentu i wreszcie przemówić własnym głosem, składającym się na wielogłos teraźniejszości kultury. W przywołanym już, zamykającym książkę fantastycznym eseju o Schulzu Nycz wskazuje na zasadę tego życia, myślenia i pisania na progu. Stylistyczna ekstrawagancja (druga formuła „innej” racjonalności) staje się cechą każdej nowości, okazuje się osobliwością nie tylko egzystencjalna, ale przede wszystkim ontologiczną - jesteśmy dziś osobliwościami pragnącymi kontaktu poprzez język, który „dopiero ma nadejść”. Ta „krańcowa” ontologia nie ma w sobie nic z kulturowego wyczerpania, przeciwnie: jest ożywcza w takim zakresie, $\mathrm{w}$ jakim nowe imię rodzi się $\mathrm{w}$ języku niczym nowy byt, nowe zdarzenie, przychodzące nie wiadomo skąd i z nieznanego czasu. Niezależnie od mesjańskiego tropu, oczywistego w kontekście twórczości autora Sklepów cynamonowych, wyraźnie zaznacza się nie teologiczna, lecz antropologiczna stawka projektu Nycza. Mówić na „końcu języka” bez popadania w patos niewyrażalnego - oto, być może, ostateczny cel wybitnej książki Ryszarda Nycza. Jak pisał Pascal Quignard:

Chodzi o ten rodzaj słownego doświadczenia, o którym wiadomo, że służyło albo samemu temu słowu, albo zapomnieniu o tym, co ludzkie, niepamięci, która atakuje nas od wewnątrz, bądź też: służyło nieprzewidzianemu, przypadkowemu charakterowi naszych myśli, kruchości naszej tożsamości, mimowolnej materii naszej pamięci oraz jej wyłącznie lingwistycznej wartości, intuicyjnie wyczuwanej i poznawanej. To doświadczenie, w którym nasze ograniczenia i nasza śmierć po raz pierwszy mieszają się ze soba. [...] Imię na końcu języka przypomina nam, że mowa nie stanowi dla nas refleksyjnego aktu. Nie jesteśmy wcale, jak by się mogło wydawać, zwierzętami mówiącymi ${ }^{1}$.

${ }^{1}$ P. Quignard, Le nom sur le bout de le langue, Paris 1995, s. 57. 
